Research Article

\title{
Sources of Agricultural Productivity Growth in SAARC Countries: The Role of Financial Development, Trade Openness and Human Capital
}

\author{
Naveed Ali ${ }^{1}$, Umar Hayat ${ }^{1 *}$, Shahid Ali ${ }^{1}$, Muhammad Imad Khan ${ }^{1}$ and Sanam Wagma Khattak ${ }^{2}$ \\ ${ }^{1}$ Department of Economics and Development Studies, University of Swat, Khyber Pakbtunkhwa, Pakistan; ${ }^{2}$ Department of \\ Economics, University of Peshawar, Khyber Pakbtunkhwa, Pakistan.
}

Abstract | Apart- from providing food to the massive population, agriculture sector contributes a big share to
South Asian GDP and it also provides employment to the fast-growing population. Examining the sources
of agriculture productivity has not attained much importance related to SAARC countries. Moreover, the
studies on the role of agriculture productivity in case of the South Asian region are limited to individual
countries. Due to the important role of agriculture productivity in the world's economy, it is imperative to
analyze the sources of agriculture productivity of the SAARC countries. This endeavor examines the impact
of financial development on agricultural productivity in case of SAARC countries for the period of 1996
to 2019 . Moreover, this study introduces trade openness, human capital, and income as important control
variables of agriculture value-added. To serve this purpose, this study utilizes CS-ARDL approach. The
results of long-run estimates show that financial development, income, trade openness and human capital
are important factors explaining agricultural productivity. Moreover, the study finds an inverted-U shaped
nexus between financial development and agriculture productivity. The results of this study have great policy
implications for SAARC countries.
Received | September 18, 2019; Accepted | March 21,2021; Published | May 28, 2021
"Correspondence | Umar Hayat, Department of Economics and Development Studies, University of Swat, Khyber Pakhtunkhwa, Pakistan;
Email: umarhayat@uswat.edu.pk
Citation | Ali, N.,U. Hayat, S. Ali,M.I. Khan and S.W. Khattak. 2021. Sources of agricultural productivity growth in SAARC countries: The role
of financial development, trade openness and human capital. Sarbad Journal of Agriculture, 37(2): 586-593.
DOI $\mid$ https://dx.doi.org/10.17582/journal.sja/2021/37.2.586.593
Keywords | Agricultural productivity, Financial development, CSARDL, SAARC countries, Trade

\section{Introduction}

Since ancient times agriculture has played a $S_{\text {prominent role in the development of human }}$ societies. It was a precursor to the advent of human civilization. Whether, it was in the shape of Indus valley civilization, Egyptian Civilization, Mesopotamian civilization, Aztec civilization, and so on so forth. Moreover, the industrial revolution became possible in Western Europe after advancements in the agriculture sector and due to trade openness (Shafaeddin, 1998). Now they were able to get ample agricultural produce by using less amount of labour. This not only ensured ample food supply to the masses but also ensured the allocation of remaining agriculture-free rawlabour and Human capital for other sectors (UNCTAD, 2015). Even today in many developing countries agriculture still holds a central position in their economies, Particularly in South Asian countries. Which holds 1.84 billion of the Global population (World Bank, 2019). Apart- from Providing Food to this massive population, the Agriculture sector also contributes a big share to South Asian Gross Domestic Product and it also provides employment to the fast-growing 
population. As in South Asia share of Agriculture is 18 percent in 2016 and accommodated $44 \%$ of the Labour force (FAO, 2020). Over timeshare of the Agriculture sector in GDP and employment has declined. As in 2003, Agriculture's share in south Asian GDP decreased from $23 \%$ in 2000 to $19 \%$ in 2017 Moreover, during the last two decades, the average growth rate of agriculture is 3.2\% for South Asian countries (Liu et al., 2020). Nevertheless, the fall in agriculture growth rate does not imply a decline in overall agriculture productivity. Among others, one reason is that the share of agriculture in the economy declines as economies grew (Apostolidou et al., 2015). Over time the cereal crops and cash crops have grown. Among cereal crops, rice has grown at the rate of $1.1 \%$, Wheat by $1.4 \%$, maize by $2.5 \%$, and sweet potatoes by $3.2 \%$ (FAO, 2020). Moreover, growth in livestock and cash crops has also occurred in South Asia. Also, the agriculture sector contributes to agriculture-based industries in south Asian countries. Thus, agriculture can be regarded as the backbone of developing countries, butmany factors impacting agriculture and overall population ranging from market volatility, natural disasters in the shape of floods, pest attacks, disease storms, and weather variability affecting agriculture. And in case of the poor performance of agriculture the population faces poor health, undernutrition, poor cognitive development, and limited adaptation to new technologies (UNCTAD, 2015), and since developing countries industry is also mostly agriculture-based so poor performance of agriculture could also lead to underemployment and overall poor performance of the whole economy. The problem of malnourishment is particularly severe in South Asia as nearly half of the world's malnourished people live in the south, where agriculture is the main source of livelihood (Pandey et al., 2016). Hence, there is a need to analyze factors affecting the agriculture sector. Literature has identified several factors affecting agriculture productivity, ranging from climatic and weather variability, human capital, GDP (per Capita), trade openness, terms of trade. However, financial development as a determinant of agriculture productivity has been received less importance. Financial development not only enablesa farmer to adopt better technology but also could enable him to purchase high yield varieties, Fertilizer, and also help to use existing technologies and capital efficiently. Financial Development could also provide a buffer to farmers against the price and market volatility and natural calamities.
This study aims to identify the sources of agriculture productivity in the case of SAARC countries from 1996 to 2019. Moreover, this study introduces trade openness, human capital, and income as important control variables of agriculture value-added.

\section{Materials and Methods}

On the role of agriculture productivity, extensive research is carried out. The bulk of literature is agreed on the positive role of agriculture productivity in affecting economic growth and development (Apostolidou et al., 2015; Awokuse and Xie, 2015; Bulagi et al., 2015). Moreover, a bulk of research is carried out to assess agriculture productivity. Anik et al. (2017) and Sujan et al. (2011) in case of four south Asian countries, Rahman and Anik (2020) in case of Bangladesh, Tripathi (2010), and Emerick (2018) in case of India, Kapri and Ghimire (2020) in case of Nepal and Yamamoto et al. (2019) in case of Indonesia estimates agriculture productivity. Moreover, in the existing literature, several studies are carried out to find out the possible factors of agriculture productivity (Adetutu and Ajayi, 2020; Nakano and Magezi, 2020; Gottlieb and Grobovšek, 2019; Wang et al., 2019). Literature has identified several factors affecting agriculture productivity, ranging from climatic and weather variability, human capital, GDP (per Capita), trade openness, terms of trade. The literature on the factors of agriculture productivity can be classified into three major groups of studies. The first group has identified income, industrialization, and urbanization as important determinants of agriculture productivity. These studies include Enu and Attah-Obeng (2013), Jiang and Li (2016) and Zakaria et al. (2019). The second group of studies considered human capital as an important factor responsible for agriculture productivity (Ndour, 2017; Aniket al., 2017).

The third group of studies introduces certain other factors such as trade, knowledge spillovers, and institutional quality (Fleming and Abler, 2013). Further, financial development is also considered an important determinant of productivity (Zakaria et al., 2019; Ssozi et al., 2019). Zakaria et al. (2019) investigate the role of financial development on agriculture productivity in South Asia countries from 1973 to 2015. Using the fully modified OLS (FMOLS) technique, the authors found that there is a nonlinear nexus between FD and agricultural productivity. Similarly, Ahmad et al. (2015) reported 
of Pakistan analyzed the FD - productivity nexus. Using Cobb Douglas production function, the authors found that financial deepness is important for agriculture productivity. Narayan (2016) analyzed the role of FD in affecting agriculture productivity of India. Performing mediation analysis, the author found that financial development through an increase in agriculture credit provides a base for raising agriculture productivity. In the study of Anthony (2010), the agriculture credit-led growth in Nigeria has been studied. The findings of the study show that agriculture credit positively affects growth. Akram et al. (2013) examine the role of agriculture credit in affecting agriculture productivity related to Pakistan. Using the Frontier production function method, the authors conclude that agriculture credit is an important factor in affecting agriculture productivity.

To sum up, in the existing literature, several factors are identified as responsible for agriculture productivity growth. However, examining the sources of agriculture productivity has not attained much importance related to SAARC countries. Moreover, the studies on the role of agriculture productivity in case of the South Asian region are limited to individual countries. Due to the important role of agriculture productivity in the world's economy, it is imperative to analyze the sources of agriculture productivity of the SAARC countries. Further, the role of financial development in affecting agriculture productivity has not gained much importance from the authors. This study fills the gap in the existing literature by analyzing the role of financial development in affecting agriculture productivity, which has great policy implications for SAARC countries. Furthermore, this endeavor contributes to the literature by introducing the nonlinear term of financial development, which has significant policy implications.

\section{Data and model specification}

Model construction: This paper examines the sources of agriculture productivity by looking at the role of income level, trade openness, and human capital. Based on the theoretical framework, the general form of AP function is given as follows:

$$
A P^{i t}=f\left(F D^{i t}, F D S^{i t}, T O^{i t}, I N C^{i t}, H C^{i t}\right)
$$

In Equation 1, $i$ is for each province such as $i=1$, ....N and $t$ is for period from 1996-2019. Similarly, the empirical specification is given in Equation 3 as following:

$A P^{i t}=\delta^{1} F D^{i t}+\delta^{2} F D S^{i t}+\delta^{3} T O^{i t}+\delta^{4} I N C^{i t}+\delta^{5} H C^{i t}+\varepsilon^{i t}$

This study uses financial development (FD), financial development square (FDS), income level (INC), human capital (HC), and trade openness (TO) as main independent variables and agriculture productivity (AP) is the dependent variable. A positive impact of FD on agriculture productivity is expected because an easy provision of credit to the farmers enables them to boost their productivity. In the existing literature, several authors argue that FD has a positive impact on agriculture productivity (Ahmad et al., 2015; Narayan, 2016; Zakaria et al., 2019; Ssozi et al., 2019). Following Fleming and Abler (2013), trade openness has been included in the empirical model of agriculture productivity. A positive impact of trade openness on agriculture productivity is expected since trade openness produced encouraging effects on the agriculture sector by enhancing its technological level. Moreover, trade openness through competition improves productivity and efficiency within the agriculture sector and hence, expands the productivity of agriculture goods. Following Enu and Attah-Obeng (2013), Jiang and Li (2016), Zakaria et al. (2019) and Nakano and Magezi (2020), income as additional explanatory variable is included in the empirical model of agriculture productivity. A positive impact of income on agricultural productivity is expected because higher-income enables farmers to adopt modern technologies and inputs that in turn affect agricultural productivity. Following Ndour (2017) and Anik et al. (2017), human capital as a core explanatory variable is included in the empirical model of agriculture productivity. The existing literature considered human capital as an important factor responsible for agriculture productivity. The main source of data is World Development Indicators (WDI).

\section{Estimation strategy}

Cross-section dependence (CSD) and slope homogeneity tests: Cross-sectional dependency is one of the most threatening problems of panel data. The traditional techniques of cointegration and unit root provide biased results in the presence of CSD and slope heterogeneity (Pesaran, 2007). To deal with panel data, it is imperative to test slope homogeneity and cross-sectional independence assumptions. The Pesaran (2015) CSD statistic equation is written as: 


$$
C S D^{N T}=\sqrt{\frac{T N(N-1)}{2}} * \hat{\bar{\rho}}_{N}
$$

In Equation 3, the pair-wise correlation coefficient is denoted by $\tilde{\rho}$. Similarly, the slope homogeneity notion is tested by means of Pesaran et al. (2008) test. The test is superior to other heterrgenuity tests due to its power to deal with CSD. Moreover, the test is applicable to a large sample size. The statistic for testing slope homogeneity is given by the following equations.

$$
\begin{aligned}
& \tilde{\Delta}_{S H}(\text { delta tilde })=(N)^{\frac{1}{2}}(2 k)^{-\frac{1}{2}}\left(\frac{1}{N} \tilde{S}-k\right) \ldots( \\
& i s H(\text { adjusted delta tilde })=(N)^{\frac{1}{2}}\left(\frac{2 k(T-k-1}{T+1}\right)^{-\frac{1}{2}}\left(\frac{1}{N} \tilde{S}-2 k\right) \ldots
\end{aligned}
$$

\section{Panel unit root test}

This study uses CIPS and Bai and Carrion-i-Silvestre (2009) unit root tests to check the order of integration of variables. The CIPS test uses cross-section averages of first difference and lagged for each observation utilizes ADF regression (Dong et al., 2018). The empirical equation of cross-section augmented Dickey-Fuller (CDF) is written as:

$\Delta Z_{i t}=\delta_{i}+\pi_{i} Z_{i, t-1}+\theta_{i} \bar{Z}_{t-1}+\sum_{l=0}^{p} \theta_{i t} \Delta \overline{Z_{t-l}}+\sum_{l=1}^{p} \gamma_{i t} \Delta Z_{i, t-l}+\varepsilon_{i t} \ldots$

Whereas, $Z_{\mathrm{r}-1}^{-}$and $\Delta^{-} Z_{t-l}$ are both the cross-section averages. CPS written below is obtained from CDF as:

$$
\mathrm{CPS}=\frac{1}{\mathrm{~N}} \sum_{\mathrm{i}=1}^{\mathrm{n}} \mathrm{CDF}_{\mathrm{i}}(7)
$$

\section{Panel cointegration approach}

This study applies Westerlund and Edgerton's (2008) panel cointegration test. The test has the ability to compute the speed at which long-run equilibrium is restored. This test is important due to the fact that it deals with CSD and slope heterogeneity (Kapetanios et al., 2011). The test equation is written as:

$y_{i t}=\alpha_{i}+F_{t}^{\prime} \theta_{i}+\beta_{i} t+z_{i, t}^{\prime} \pi_{i}+\left(D M_{i, t} z_{i, t}\right)^{\prime} \tau_{i}+\mu_{i, t}$

In Equation 8, $D M_{i t}=1\left(t>T_{i}\right)$ with $T_{i}$ shows structural breaks for cross-section $i$ and $z_{i t}$ follows an $I(1)$ process.
The CS-ARDL approach for long run estimates

To estimate the long-run estimation, this study uses CS-ARDL approach. The approach is superior to other approaches due to the fact that it deals with endogeneity, small sample bias error and CSD (Chudik and Pesaran, 2015). The specification for CS-ARDL is given as:

$A P^{i t}=\delta^{o}+\sum_{j=1}^{p} \delta^{i t} C O_{2}^{i, t-j}+\sum_{j=0}^{p} \dot{\alpha}_{\mathrm{it}} \mathrm{W}_{\mathrm{t}-\mathrm{j}}+\sum_{j=0}^{3} \hat{\mathrm{v}}_{\mathrm{it}} \bar{z}_{\mathrm{t}-\mathrm{j}}+\varepsilon^{i t}$

Where; $Z_{t}=\left(\Delta A P^{\prime, t} W\right)$ contain cross-section averages and explanatory variables are included in $\mathrm{W}_{\mathrm{it}}=\left(F D^{i t}\right.$, $\left.F D S^{i t}, I N C^{i t}, T O^{i t}, H C^{i t}\right)$.

\section{Results and Discussion}

The results of the CSD test show that all variables are cross-sectionally dependent. These results show that SAARC countries are dependent on each other. A shock in one of the variables in one of the SAARC countries has implications for the same variable in other counties. Hence, the economic shocks in one country affect other countries. Moreover, the slope heterogeneity problem in model 1 is also evident (see Table 1). The results of both unit root tests show that the variables are mixed order of integration (see Tables 2 and 3).

Table 1: Cross-section dependence and slop homogeneity analysis.

$\begin{array}{ll}\text { Pesaran (2015) CSD Test } \\ \text { Variables } & \text { CSD-Statistic } \\ \text { AP } & 85.54^{* * *} \\ \text { FD } & 84.73^{* * *} \\ \text { INC } & 92.08^{* *} \\ \text { HC } & 77.71^{* * *} \\ \text { TO } & 81.64^{* * *}\end{array}$

Pesaran and Yamagata (2008) slope homogeneity test $\sim 16.53^{* * *}$ $\sim$ Adjusted $\quad 16.01^{* * *}$

Note: ***, ***, * denote significance level at 1\%, 5\% and $10 \%$.

The results of Westerlund and Edgerton's (2008) show that there islong-run cointegration between agriculture productivity, financial development, income, human capital and trade openness. The long-run cointegration between variables in model 1 is evident from the significant test statistics at level and regime shift. 
Table 2: Panel unit root analysis (Pesaran, 2007).

\begin{tabular}{llllll} 
Variables & \multicolumn{3}{c}{ Level } & First difference & Integration order \\
& Constant & Constant and trend & Constant & Constant and trend & \\
AP & -1.813 & -1.863 & $-4.092^{* * *}$ & $-4.711^{* * * *}$ & $\mathrm{I}(1)$ \\
FD & -1.412 & -1.872 & $-3.287^{* * * *}$ & $-4.191^{* * * *}$ & $\mathrm{I}(1)$ \\
INC & $-3.154^{* * * *}$ & $-3.652^{* * * *}$ & --- & -- & $\mathrm{I}(0)$ \\
HC & -1.021 & -1.329 & $-4.713^{* * * *}$ & $-4.092^{* * * *}$ & $\mathrm{I}(1)$ \\
TO & $-4.734^{* * * *}$ & $-4.118^{* * * *}$ & --- & --- & $\mathrm{I}(0)$
\end{tabular}

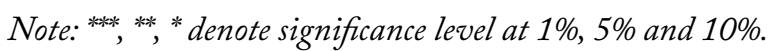

Table 3: Results of Bai and Carrion-i-Silvestre (2009) unit root test.

\begin{tabular}{llllllll} 
Variables & Level & \multicolumn{9}{c}{ First Difference } & \multicolumn{2}{l}{ Integration order for } \\
& $\boldsymbol{Z}$ & $\boldsymbol{P}_{\boldsymbol{m}}$ & $\boldsymbol{P}$ & $\boldsymbol{Z}$ & $\boldsymbol{P}_{\boldsymbol{m}}$ & $\boldsymbol{P}$ & variables \\
AP & $-2.48^{* * * *}$ & $3.37^{* * *}$ & $76.23^{* * *}$ & - & - & - & $\mathrm{I}(0)$ \\
FD & -0.432 & $-2.03^{* *}$ & 22.52 & $-3.43^{* * *}$ & $47.15^{* * * *}$ & $343.22^{* * * *}$ & $\mathrm{I}(1)$ \\
INC & -0.35 & $-1.89^{* * *}$ & 32.38 & $-3.74^{* * *}$ & $38.26^{* * *}$ & $411.25^{* * *}$ & $\mathrm{I}(1)$ \\
HC & $-2.51^{* * * *}$ & $1.98^{* * *}$ & $47.49^{* * *}$ & - & - & - & $\mathrm{I}(0)$ \\
TO & $-1.61^{*}$ & 0.35 & $37.13^{*}$ & - & - & - & $\mathrm{I}(0)$
\end{tabular}

****, ***, * denote significance level at $1 \%, 5 \%$ and $10 \%$.

Hence, the regime shift does not change the cointegration between variables. The cointegration results are provided in Table 4.

Table 4: Cointegration analysis with structural breaks.

$\begin{array}{lll} & \boldsymbol{\tau}_{\mathrm{n}} & \boldsymbol{\varphi}_{\mathrm{n}} \\ \text { Level Shift } & -2.717^{* * * *} & -4.119^{* * * *} \\ \text { Regime Shift } & -1.832^{*} & -3.249^{* * * *}\end{array}$

Note: ***** and * denote significance level at $p<0.01$ and 0.10 .

Table 5: $C S-A R D L$ long-run and short-run empirical analysis.

\begin{tabular}{|c|c|c|}
\hline Variables & Long run coefficients & Short-run coefficients \\
\hline FD & $0.812^{* *}(0.467)$ & $0.558^{*}(0.429)$ \\
\hline FDS & $0.085^{* * * *}(0.028)$ & $0.104^{* * *}(0.031)$ \\
\hline INC & $0.093^{*}(0.027)$ & $0.053^{*}(0.029)$ \\
\hline $\mathrm{HC}$ & $0.082 *(0.051)$ & $0.041^{*}(0.031)$ \\
\hline TO & $0.061^{* *}(0.031)$ & $-0.019^{* * *}(0.009)$ \\
\hline $\operatorname{ECM}(-1)$ & --- & $0.995^{* * *}(0.051)$ \\
\hline
\end{tabular}

Note: ******, * denote significance level at $1 \%, 5 \%$ and $10 \%$.

For estimating long-run coefficients, a robust CSARDL method is applied. The method is superior to other methods due to its applicability to the model with slope heterogeneity, unobserved common factors, endogeneity, and cross-section dependence among variables (Pesaran and Tosetti, 2011). The issue of cross-section dependence is tackled via cross-section averages in the model (Chudik and Pesaran, 2015). Table 5 shows the results of longrun estimates provided by CS-ARDL approach. The long-run elasticities of financial development, income, human capital, and trade openness are $0.983 \%, 0.071,0.071 \%$, are 0.052 respectively. Table 5 reveals numerous eye-catching results. First, the positive coefficient of FD and the negative significant coefficient of FDS confirm that there is a nonlinear relationship between financial development and agriculture productivity i.e. inverted-U shaped. The negative and significant lagged error correction term confirms convergence to long-run equilibrium. In the short run, the inverted- $U$ shaped association between financial development and agriculture productivity is confirmed. The positive coefficient of FD in the long run supports the earlier findings of Ahmad et al. (2015), Narayan (2016), Zakaria et al. (2019) and Ssozi et al. (2019). Moreover, in the short run, income, human capital, and trade openness are important factors in affecting agriculture productivity. In the long run trade openness positively affects agriculture value-added, which support the earlier finding of Fleming and Abler (2013). Trade openness produced encouraging effects on the agriculture sector by enhancing its technological level. Moreover, trade openness through competition improves productivity and efficiency within the agriculture sector and hence, expands the productivity of agriculture goods. It is 
evident that human capital is positively related with agriculture productivity in the long run, which support the earlier findings of Ndour (2017) and Anik et al. (2017). Human capital is considered as an important factor responsible for agriculture productivity. Further, the coefficient of income is positive and significant, which implies that income as an important variable in improvement of agriculture productivity. Higherincome enables farmers to adopt modern technologies and inputs that in turn affect agricultural productivity. These results are parallel with the findings of Enu and Attah-Obeng (2013), Jiang and Li (2016), Zakaria et al. (2019) and Nakano and Magezi (2020). Overall, the results also support the findings of Rahmanand Anik (2020), Tripathi (2010), Emerick (2018), Kapri and Ghimire (2020) and Yamamoto (2019). These studies have investigated the factors of agriculture productivity in different SAARC countries. Hence, the findings of the present study greatly relate to other SAARC conclusions.

\section{Conclusions and Recommendations}

This study examines the impact of financial development on agriculture value-added in terms of the SAARC countries. Moreover, this study introduces trade openness, human capital, and income as important factors of agriculture value-added. To serve this purpose, this study utilizes advanced econometric methodology. This study applies Westerlund and Edgerton's panel cointegration test. The test can compute the speed at which long-run equilibrium is restored. To estimate the long-run estimation, CSARDL approach is used. The results of CSD test show that all variables are cross-sectionally dependent. These results show that SAARC countries are dependent on each other. A shock in one of the variables in one of the SAARC countries has implications for the same variable in other counties. Hence, the economic shocks in one country affect other countries. The results of cointegration test show that there is longrun cointegration between agriculture productivity, financial development, income, human capital and trade openness. The results of long-run estimates show that financial development, income, human capital, and trade openness are important factors explaining agriculture value-added. The positive coefficient of FD and the negative significant coefficient of FDS confirm that there is a nonlinear relationship between FD and agriculture productivity, i.e., inverted-U shaped.
The results of this study have significant policy implications for the SAARC countries. It is suggested that SAARC countries should make the financial system more friendly to farmers. Since, majority of the formers are poor and they have limited access to financial products. Strong financial system will enable them to adopt better technology and could enable them to purchase high yield varieties, fertilizer. A strong financial system provides a buffer to farmers against the price and market volatility and natural calamities. Moreover, the SAARC countries should focus more on their human capital. Developed human capital will enable the formers to use the existing technologies and capital efficiently.

\section{Novelty Statement}

This study fills the gap in the existing literature by analyzing the role of financial development in affecting agriculture productivity, which has great policy implications for SAARC countries.

\section{Author's Contribution}

Naveed Ali: Conceptualized the idea for this research and developed the overall methodology to conduct the research.

Umar Hayat: Assisted in the data pertaining to agriculture section in the manuscript.

Shahid Ali: Assisted in the analytical part of the research.

Muhammad Imad Khan: Contributed in the review of relevant literature from various sources.

Sanam Wagma Khattak: Contributed in the review of relevant literature from various sources.

\section{Conflict of interest}

The authors have declared no conflict of interest.

\section{References}

Adetutu, M.O. and V. Ajayi. 2020. The impact of domestic and foreign $\mathrm{R}$ and $\mathrm{D}$ on agricultural productivity in sub-Saharan Africa. World Dev., 125: 104690. https://doi.org/10.1016/j. worlddev.2019.104690

Ahmad N., I. Jan, S. Ullah and S. Pervez. 2015. Impact of agricultural credit on wheat productivity in District Jhang, Pakistan. Sarhad J. Agric., 31: 65-69. 
Akram W., Z. Hussain, N. Ahmad and I. Hussain. 2013. Does agriculture credit affect production efficiency? Frontier production function approach. Pak. Econ. Soc. Rev., 51: 179-190.

Anik, A.R., S. Rahman and J.R. Sarker. 2017. Agricultural productivity growth and the role of capital in South Asia (1980-2013). Sustainability, 9: 470. https://doi.org/10.3390/ su9030470

Anthony, E., 2010. Agricultural credit and economic growth in Nigeria. An empirical analysis: Economics department, Ambrose Ali University Ekpoma, Nigeria.

Apostolidou, I., K. Mattas, E. Loizou and A. Michailidis. 2015. Agriculture's role in economic growth: An exploratory study among southern and northern EU countries EU crisis and the role of the periphery. Springer. pp. 147-162. https://doi.org/10.1007/978-3-31910133-0_9

Awokuse, T.O. and R. Xie. 2015. Does agriculture really matter for economic growth in developing countries? Can. J. Agric. Econ., 63(1): 77-99. https://doi.org/10.1111/cjag.12038

Bai, J. and J. L. Carrion-i-Silvestre, 2009. Structural changes, common stochastic trends, and unit roots in panel data. Rev. Econ. Stud., 76(2): 471-501.

Bulagi, M., J. Hlongwane and A. Belete. 2015. Causality relationship between agricultural exports and agricultures share of gross domestic product in South Africa: A case of avocado, apple, mango and orange from 1994 to 2011. Afr. J. Agric. Res., 10(9): 990-994. https://doi. org/10.5897/AJAR2014.8548

Chudik, A. and M.H. Pesaran. 2015. Common correlated effects estimation of heterogeneous dynamic panel data models with weakly exogenous regressors. J. Econ., 188(2): 393-420.

Dong, K., R. Sun, H. Jiang and X. Zeng. 2018. $\mathrm{CO} 2$ emissions, economic growth, and the environmental Kuznets curve in China: What roles can nuclear energy and renewable energy play? J. Clean. Prod., 196:51-63. http://dx.doi. org/10.1016/j.jclepro.2018.05.271

Douglas, G., 2010. Agricultural productivity and economic growth, 4: 3825-3866. https://doi. org/10.1016/S1574-0072(09)04073-0

Emerick, K., 2018. Agricultural productivity and the sectoral reallocation of labor in rural India. J. Dev. Econ., 135: 488-503. https://doi. org/10.1016/j.jdeveco.2018.08.013

Enu, P. and P. Attah-Obeng. 2013. Which macro factors influence agricultural production in Ghana? Acad. Res. Int., 4: 333.

FAO, 2020. State of food and agriculture in asia and the pacific region, including future prospects and emerging issues. FAO Regional Conference for Asia and the Pacific, Thimphu, Bhutan, 17-20 February 2020.

Fleming, D.A. and D.G. Abler. 2013. Does agricultural trade affect productivity? Evidence from Chilean farms. Food Policy, 41: 11-17. https://doi.org/10.1016/j.foodpol.2013.04.004

Gong, B., 2020. Agricultural productivity convergence in China. China Econ. Rev., 60: 101423. https://doi.org/10.1016/j. chieco.2020.101423

Gottlieb, C. and J. Grobovšek. 2019. Communal land and agricultural productivity. J. Dev. Econ., 138: 135-152. https://doi.org/10.1016/j. jdeveco.2018.11.001

Jiang, L. and Z. Li. 2016. Urbanization and the change of fertilizer use intensity for agricultural production in Henan Province. Sustainability. 8: 186. https://doi.org/10.3390/su8020186

Jin, G., Z. Li, X. Deng, J. Yang, D. Chen and W. Li. 2019. An analysis of spatiotemporal patterns in Chinese agricultural productivity between 2004 and 2014. Ecol. Ind., 105: 591-600. https://doi. org/10.1016/j.ecolind.2018.05.073

Kapetanios, G., M.H. Pesaran and T. Yamagata. 2011. Panels with non-stationary multifactor error structures. J. Econ.,160(2): 326-348.

Kapri, K. and S. Ghimire. 2020. Migration, remittance, and agricultural productivity: Evidence from the Nepal Living Standard Survey. World Dev. Perspect., pp. 100198. https://doi.org/10.1016/j.wdp.2020.100198

Liu, J., M. Wang, L. Yang, S. Rahman and S. Sriboonchitta. 2020. Agricultural productivity growth and its determinants in south and southeast Asian countries. Sustainability, 12: 4981. https://doi.org/10.3390/su12124981

Nakano, Y. and E.F. Magezi. 2020. The impact of microcredit on agricultural technology adoption and productivity: Evidence from randomized control trial in Tanzania. World Dev., 133: 104997. https://doi.org/10.1016/j. worlddev.2020.104997

Narayanan, S., 2016. The productivity of agricultural credit in India. Agric. Econ., 47: 399-409. 
https://doi.org/10.1111/agec.12239

Ndour, C.T., 2017. Effects of human capital on agricultural productivity in Senegal. World Sci. News., pp. 34-43.

Padey, V.L., S.M. Dey and U. Jayachanran. 2016. Impact of agricultural interventions on the nutritional status in South Asia: A review. Food Policy. https://doi.org/10.1016/j. foodpol.2016.05.002

Pesaran, M.H., 2007. A simple panel unit root test in the presence of cross-section dependence. J. Appl. Econom., 22: 265-312.

Pesaran, M.H., A. Ullah and T. Yamagata. 2008. A bias-adjusted LM test of error cross section independence. Econom. J., 11:105-127.

Pesaran, M.H., 2015. Testing weak cross-sectional dependence in large panels. Econom. Rev., 34(6-10): 1089-1117.

Rahman, S. and A.R. Anik. 2020. Productivity and efficiency impact of climate change and agroecology on Bangladesh agriculture. Land Use Policy. Elsevier, 94(C): 104507. https://doi. org/10.1016/j.landusepol.2020.104507

Shafaeddin, M. 1998. How did developed countries industrialize? the history of trade and industrial policy: the case of Great Britain and the USA, Discussion Paper no. 139, Geneva, UNCTAD.

Ssozi, J., S. Asongu and V.H. Amavilah. 2019. The effectiveness of development aid for agriculture in Sub-Saharan Africa. J. Econ. Stud., 46(2): 284-305. https://doi.org/10.1108/JES-112017-0324

Sujan, P., K. Akira and Y. Hironori. 2011. Sources of agricultural productivity growth in south and Southeast Asia. Trends Agric. Econ., 4: 18-29. https://doi.org/10.3923/tae.2011.18.29

Tripathi, A., 2010. Total factor productivity growth in Indian agriculture. J. Glob. Econ., 6: 286298. https://doi.org/10.1956/jge.v6i4.67

UNCTAD, 2015. The least developed countries report: Transforming rural economies. United Nations publication. Sales No. E.15.II.D.7. New York and Geneva.

Wang, S.L., J. Huang, X. Wang and F. Tuan. 2019. Are China's regional agricultural productivities converging: How and why? Food Policy, 86: 101727. https://doi.org/10.1016/j. foodpol.2019.05.010

Westerlund, J. and D.L. Edgerton. 2008. A simple test for cointegration in dependent panels with structural breaks. Oxford Bull. Econ. Stat., 70(5): 665- 704.

World Bank, 2019. The World Bank Annual Report 2019: ending poverty, investing in opportunity. Washington, DC. https://openknowledge. worldbank.org/handle/10986/32333

Yamamoto, Y., Y. Shigetomi, Y. Ishimura and M. Hattori. 2019. Forest change and agricultural productivity: Evidence from Indonesia. World Dev., 114: 196-207. https://doi.org/10.1016/j. worlddev.2018.10.001

Zakaria, M., W. Jun and M.F. Khan. 2019. Impact of financial development on agricultural productivity in South Asia. Agric. Econ., 65: 232-239. https://doi.org/10.17221/199/2018AGRICECON 